\title{
How I Learned to Stop Worrying and Love the Crisis*
}

\author{
Jan Fidrmuc ${ }^{\mathrm{a}, \mathrm{cd},{ }^{\dagger},}$ and Ariane Tichit ${ }^{\mathrm{b}}$ \\ ${ }^{a}$ Department of Economics and Finance and CEDI, Brunel University \\ ${ }^{\mathrm{b}}$ CERDI, University of Auvergne \\ ${ }^{\mathrm{c}}$ Institute of Economic Studies, Charles University \\ ${ }^{\mathrm{d}}$ CESifo Munich
}

March 2013

\begin{abstract}
We investigate the effects of economic crises on the subsequent economic performance, economic reform, democratization and institutional change. Our analysis is based on a sample of post-communist countries, most of which experienced severe economic crises during the 1990s. We find that the severity of crisis has had a positive impact on the subsequent pace of economic reform, economic growth and, with a delay, on investment and institutional change. Episode of high inflation, moreover, translate into lower subsequent inflation. Crises thus serve as catalysts of reform and institutional change and lead to better long-term economic performance.
\end{abstract}

Keywords: crisis, transition, growth, inflation, reform, institutions.

JEL Codes: O11, O47, P27

\footnotetext{
${ }^{*}$ We benefited from helpful comments and suggestions received from seminar participants at Brunel University, University College London and Université des Sciences et Technologies de Lille 1.

$\dagger$ Corresponding Author. Department of Economics and Finance and Centre for Economic Development and Institutions (CEDI), Brunel University; Institute of Economic Studies, Charles University; and CESifo Munich. Contact information: Department of Economics and Finance, Brunel University, Uxbridge, UB8 3PH, United Kingdom.Jan.Fidrmuc@brunel.ac.uk or jan@fidrmuc.net. http://www.fidrmuc.net/. Phone: +44-1895-266-528.
} 


\section{Introduction}

Why do countries undertake systemic reforms of their economies? An important motivation is the desire and need to improve the wellbeing of their citizens. However, while the long-term outcome of economic reforms is uncertain, they are typically associated with substantial costs and economic hardship in the short run (Roland, 2000, chapters 2 and 3). As a result, efficiency-enhancing reforms may be rejected by the voters even if they are expected to benefit the majority of them (Fernandez and Rodrik, 1991; Rodrik, 1999). Alternatively, the required reforms may get postponed inefficiently long, thus prolonging the economic inefficiency that precedes them (Alesina and Drazen, 1991).

Alesina and Drazen (1991) make an intriguing proposition based on these stylized facts. They argue that reforms are postponed because they are preceded by a war of attrition over the distribution of their costs. As long as the economic situation is bearable, the cost of reform could be imposed only on specific segments of the society: a moderate fiscal stabilization, for example, can be achieved by increasing taxes, lowering redistributive transfers, or laying off some civil servants. Each of those groups has much at stake and will therefore oppose the reform if it places the brunt of the cost on them and favor it otherwise. The economic situation then worsens progressively until, for one of the parties concerned, the cost of postponing the reform any further exceeds the cost of implementing it. That group then accepts to bear a disproportionate share of the burden and the reform can get underway. They observe, for example, that it is typically easier to drum up wide-spread political support for a stabilization program when inflation reaches hyperinflationary proportions but not during the preceding (often long) period of moderately high inflation. In other words, reform only gets implemented when the underlying situation reaches crisis proportions and becomes unsustainable: things have to get really bad before they can start getting better.

This 'crises beget reforms' hypothesis has received some empirical support. Bruno and Easterly $(1996,1998)$ find that growth accelerates following high-inflation crises and that crisis-stricken countries tend to stabilize inflation, liberalize and open up their economies and privatize public assets. Drazen and Easterly (2001), similarly, find that extreme values of inflation and black-market premiums tend to be followed by more dramatic improvements in subsequent performance than moderate ones. Drazen and Easterly consider also the effect of growth crises but fail to find any evidence that they foster subsequent improvements. In contrast, Pitlik and Wirth (2003), who consider both growth and inflation crises, find that deep crises of either type foster subsequent economic reform whereas moderate crises have little or no effect. Lora and Olivera (2004) find that crises indeed appear to make reforms more likely in Latin America. Cavallo and Cavallo (2010), finally, argue that the macroeconomic effect of crises depends on the prevailing institution: in democratic countries, the negative effect of crises on growth is less severe than in non-democratic countries.

Crises can also have important political repercussions. The economic and political changes in Eastern Europe during the 1990s and the recent Arab Spring in the Middle East alike were, to a large extent, precipitated by the failures of the incumbent regimes to maintain and improve the wellbeing of their citizens. Nevertheless, crises also can hinder reform. The studies of voting behavior in post-communist countries find that economic contractions undermine support for pro-reform parties and may lead to such parties being voted out of office (Fidrmuc, 2000 a,b; Jackson, Klich and Poznańska, 2001; Tucker, 2002). Such political reversals, in turn, may allow the winners of partial reform to capture the government and stall the reform momentum (Hellman, 1998). This suggests that there is indeed a thin line between vicious and virtuous crises (Krueger, 1993): some crises generate political consensus in favor 
of reform while others instead lead to the reform being abandoned.

We contribute to this growing and exciting literature by exploring the effect of crises on a broad range of outcomes, both economic and political. One issue in this respect is that episodes of crises and fundamental reforms are relatively rare. Therefore, rather than address this question in a large data set with only relatively few observations of crises or reform, we focus on a sample that is rich both in reform and crisis episodes: the post-communist countries. These countries were all characterized by a high degree of government interference in their economies, high to exclusive public ownership of productive assets and high to complete central control over prices. All experienced deteriorating economic performance in the course of the 1980s which eventually lead to (attempted) systemic reforms in the early 1990s. There was, however, substantial variation in terms of reforms implemented and their outcomes. Some countries implemented ambitious reforms early on and, in a space of a few years, managed to achieve Western-style democratic regimes and market-economy systems. Others muddled through, reversed previously implemented reforms and/or suffered state capture by interest groups. In terms of growth, some countries experienced relatively mild recessions and started recovering after 2-5 years (Poland, Czech Republic but also Uzbekistan). Other post-communist countries saw their output falling by as much as twothirds (Moldova, Tajikistan) or even three quarters (Georgia) of the pre-transition level, with the recession lasting in some cases as long as a decade. While most transition economies experienced episodes of high inflation, some managed to bring inflation under control quickly; others suffered protracted periods of high inflation or hyperinflation.

We use this variation in the severity of transition-induced crises as well as in the economic and institutional outcomes to analyze the legacy of crises. The scope of our analysis is thus broader than any of the previous contributions. We identify crises both as taking the shape of economic contractions and high inflation. In turn, we consider the effect of crises on the subsequent economic reform, democratization, multiple measures of economic performance and institutional change.

After briefly introducing the data in the following section, section 3 presents the results of our analysis of the impact of crises on economic liberalization, growth, investments, inflation and institutional change and section 4 summarizes our findings.

\section{Data}

Our analysis covers all post-communist countries for which data are available. Altogether, we consider 29 countries $^{3}$ that used to belong to the Soviet zone of influence, including the former constituent republics of the Soviet Union, Yugoslavia and Czechoslovakia, over the period from 1990 to 2008. The starting point is limited by data availability: little information on these countries is available for the earlier years. Furthermore, the reforms we consider were mostly initiated after 1990 (the main exception is former Yugoslavia which experienced limited and partial reforms already during the 1980s). We include data through to 2008 so as to eliminate the current economic crisis. The aftermath of the current crisis is not revealed yet so that including it could confound our results on the effects of the earlier transition-induced crises.

To capture the progress in implementing market-oriented reforms, we use the average of

\footnotetext{
3 Albania, Armenia, Azerbaijan, Belarus, Bosnia-Herzegovina, Bulgaria, Croatia, Czech Republic, Estonia, Georgia, Hungary, Kazakhstan, Kyrgyzstan, Latvia, Lithuania, Macedonia, Moldova, Mongolia, Monte Negro, Poland, Romania, Russia, Serbia, Slovakia, Slovenia, Tajikistan, Turkmenistan, Ukraine and Uzbekistan.
} 
the eight progress-in-transition indicator compiled and published annually by the EBRD. ${ }^{4} \mathrm{We}$ exploit the World Bank Development Indicators 2009 as the source of all macroeconomic variables, except for unemployment rates which we obtained from the EBRD Transition Reports (various issues). We use the average Freedom House democracy index 5 and Kaufmann and al.'s (2009) governance indicators to take account of the progress in political and institutional transitions. Finally, we code whether countries were engaged in military conflict (external or internal) based on the Correlates of War (2010) dataset.

The starting point of our analysis is to identify and measure the severity of the transitioninduced recession in post-communist countries. The immediate causes of the recession were multiple: disruption of trade with the Eastern Block countries that was only slowly counterbalanced by growing trade with the West, price liberalization which translated repressed inflation to open inflation and the resulting fall in consumption, privatization of state-owned enterprises and the hardening of the budget constraints, resulting in falling employment, disorganization due to disruption of traditional business ties between the formerly state-owned firms, and so on (see Kornai, 1994, and Roland, 2000, and the references therein).

The transformational recession manifested itself most visibly in falling output and rapidly rising prices. ${ }^{6}$ We therefore base our crisis measures on the trajectories of output and inflation since the outset of reform. Figures 1 and 2 illustrate the outcomes experienced by the postcommunist countries: Figure 1 depicts the index of overall GDP in each year as percentage of the 1989 value, while Figure 2 displays the cumulative price level increase, with each data point showing the multiple of the initial price level (so that a value of 2 corresponds to 100 percent cumulative inflation). It is not possible to identify individual countries in either Figure. Instead, they are intended to indicate the range of outcomes observed in our data. Virtually all counties experienced an output fall along a J-shaped trajectory (see Figure 1): the initial contraction was followed by a recovery, in some cases after considerable delay, however. The country with the deepest output fall is Bosnia-Herzegovina, whose output fell to 13.5 percent of the 1989 level by 1992, followed by Georgia (23.5 percent in 1994); both countries were affected by internal conflicts. The best outcome is reported by Turkmenistan (output rising to 226 percent by 2008), followed by Poland (201 percent). The initiation of economic reform was associated with an upsurge of in all post-communist countries (Figure 2 ). The range of outcomes varies widely, however: the average price level has increased 4.5 times in the Czech Republic by 2008 while it rose to 1.3 billion times the original level in Serbia

To reflect this diversity of transformational recessions in our analysis, we construct measures of the cumulative output fall (in percent) and cumulative price increase since 1989. For both measures, we are interested only in the crisis part of the evolution of the output and price levels. Therefore, we only consider the overall contraction of output and not the subsequent recovery. In other words, once output reaches the bottom of its post-1989

\footnotetext{
4 These indicators measure each country's progress in the following fields: price liberalization, foreign exchange and trade liberalization, small scale privatization, large scale privatization, enterprise reform, competition policy, banking reform and non-banking financial institutions. Each indicators ranges from 1 (unreformed centrallyplanned economy) to 4+ (liberal market economy). As is common in this literature, we replace plus and minus distinctions by adding and subtracting 0.33 (so that $4+$ becomes 4.33 while 4 - is 3.67 ). We do not use the more recently available EBRD indicators of infrastructure reform, only the eight original indicators measuring progress in Washington-consensus reform (liberalization, stabilization and privatization).

${ }^{5}$ Specifically, this index is the average of the Freedom House measures of political freedoms and civil liberties, rescaled so that higher values correspond to more democracy. It ranges between 1 (autocracy) to 7 (fully free).

${ }^{6}$ Unemployment could be a third manifestation of the crisis but it is less reliable because countries often use different definitions to measure it.
} 
trajectory, we keep the cumulative output fall at the level attained at this lowest point. ${ }^{7}$ The cumulative inflation measure is constructed in a similar way: it an index of the overall cumulative price increase since 1989 (i.e. value of 2 corresponds to a doubling of the price level, 10 implies a ten-fold increase in prices, etc.). Once inflation has been stabilized, the index again stays at the level attained at the time of stabilization. We define stabilization as inflation of $80 \%$ pa or lower: most countries in our data set succeed in controlling inflation after it has been brought down to two-digit levels.

Our objective is to see whether the severity of transition-induced recession has had a lasting impact on the subsequent pace of market-oriented reform, economic performance and other outcomes of interest. The cumulative inflation variable similarly captures the legacy of high inflation in the past even after run-away inflation has been stopped. Once the crisis is over, these variables no longer vary over time. Therefore, we construct a "time after crisis" variable which takes the value 0 during the crisis, and becomes a time trend thereafter. We interact this time variable with the output fall and cumulative inflation variables to test whether the effect of the crisis diminishes or strengthens over time.

\section{Long-term Effect of Crises}

First, we consider the impact of output fall on the progress in implementing market oriented reform. The results are presented in Table 1. The dependent variable is the speed of reform, proxied by the first difference in the average of eight EBRD progress-in-transition indicators. Each regression includes the lagged level of this index to account for the past level of reform: holding everything else constant, a country can implement more reform if its starting level of reform is low. We also include the lagged level of the average Freedom House democracy index to account for the possible reform-fostering effect of democratization (Fidrmuc, 2003), and a dummy for countries experiencing a military conflict. Except for the war dummy, all independent variables are lagged in order to avoid potential endogeneity problems. All regressions contain fixed effects panel regressions. ${ }^{8}$

Column (1) presents the most parsimonious specification. We find that the lagged reform index has negative influence on reform: this is not surprising given that the reform index is bound from above. The past level of democracy, on the other hand, fosters economic reform: countries that undertake political liberalization also tend to engage in more ambitious economic reform. Not surprisingly, countries affected by war make less progress with respect to reform. Finally, the primary variable of interest, output fall, is positive and highly significant: countries that experienced a deeper contraction, ceteris paribus, respond to this by accelerating economic reform. It is possible, however, that this effect is found only because output fall is correlated with some other influential variable. In column (2), we therefore replace output fall with lagged per-capita GDP (in thousands of PPP US dollars) to capture the effect of the level of economic development on the progress in reform. Its effect is negative and significant: richer countries implement less reform. However, when we include both output fall and GDP per person side by side in column (3), only the output fall remains significant while GDP per capita now has no effect on reform. In column (4), we add lagged

\footnotetext{
${ }^{7}$ In several cases, a country in question experienced a double-dip recession. One example is Russia where output initially started to recover in 1997 only to fall further in 1998 following its economic and financial crisis. In that case, we consider the deeper dip out of the two as the bottom of the transformational recession (the second dip in 1998 in Russian case).

${ }^{8}$ In addition, dynamic panel models with fixed effects such as those that we estimate here can result in dynamic bias. However, results obtained with GMM are very similar to those presented here.
} 
inflation (in logs to reduce the influence of episodes of extremely high inflation). Its effect is positive and significant: a recent experience of high inflation helps accelerate reforms. Yet, the effect of output fall remains strongly significant and essentially unchanged. Finally, the last column introduces the quadratic polynomial of time since the end of crisis: on its own and interacted with the output fall. ${ }^{9}$ The quadratic time trend can potentially capture the timespecific profile of reform while the interaction term between time and output fall will show whether the effect of crises on subsequent reform strengthens or diminishes over time. None of these variables are significant, however: the effect of crises on reform does not appear to vary over time.

Next, in Table 2, we consider the effect of crises on the first differences of the individual EBRD sub-indexes. These regressions replicate column (4) of Table 1, except the dependent variable and the lagged index of reform now is the sub-index denoted in the heading of each column. The results are remarkably consistent across the eight sub-indexes and are similar to those obtained with the average index: lagged sub-index of reform has a negative effect, lagged democracy has a positive effect and output fall again displays a positive and strongly significant effect on subsequent progress in reform. Hence, having experienced a crisis in the past stimulates progress across all aspects of the reform program. While the coefficients estimated for the various sub-indexes are quite similar to each other (and to the result reported in column 4 of Table 1), the crisis effect is particularly pronounced for the removal of price controls, liberalization of foreign trade and small-scale privatization.

So far, we have shown that having experienced a crisis fosters economic reform. Inasmuch as economic reform improves economic policy making, the legacy of a crisis should, indirectly, improve economic performance too. We therefore turn, in Table 3, to investigating whether crises affect economic performance also directly. The dependent variable is the growth rate of per-capita GDP. Each regression controls again for the lagged reform index. We also include the investment to GDP ratio and control again for military conflicts. Reform progress, as expected, has a positive coefficient: countries that have implemented more ambitious reform are rewarded by faster growth. Somewhat surprisingly, investment is never significant. Military conflicts impose a heavy penalty on economic performance. Importantly, past output contraction translates into faster subsequent growth. This effect is robust to controlling for the economic convergence effect by including the lagged GDP per person (which appears with a negative coefficient, as is standard in the growth literature, but its coefficient is not significant when included alongside the output fall, see columns 2 and 3) and inflation (which lowers growth, see column 4). Finally, in column (5), we again introduce the quadratic polynomial of time since end of crisis and its interactions with output fall. The quadratic time trend is not significant but the interaction terms are. Specifically, we observe an inverted U-shaped pattern: the positive effect of the crisis initially strengthens but eventually declines again. ${ }^{10}$

In Tables 4 and 5, we consider the effect of output fall on investment to GDP ratio and the ratio of inward FDI to GDP. Investment is an important determinant of growth (even though the preceding set of regressions failed to confirm this for our set of countries). FDI, besides bringing in additional capital into the country, can also be associated with important technological spillovers. The regressions follow similar structure as those in the preceding

\footnotetext{
${ }^{9}$ We also test for non linear effect of output fall itself by introducing it in quadratic form but it was insignificant. This result is available upon request.

10 We also introduce a quadratic term of output fall and find a $U$ shaped relationship between output fall and growth. However, the minimum of the function stands at 13.1, which is below the lowest observed output fall in our sample (Belarus in 1992 with an output fall of 13.35). Therefore, output fall has always a positive effect on growth.
} 
Tables. Again, the lagged reform index has a strong positive effect on investment and also on FDI (although the coefficient estimated for the latter is not always significant). The effect of past crises, however, now appears significantly negative: having had a crisis in the past discourages both domestic investment and inflow of investment from abroad. For investment, however, this is counteracted by a positive time-varying effect of past crises, as reflected in the positive interaction between output fall and time since crisis. Hence, investment declines in the aftermath of crises but then catches up later.

Table 6 considers the effect of crises on inflation, which is never significant. Hence, crises, at least inasmuch as they are manifested in economic contractions, do not affect the subsequent inflation (we consider the effect of high-inflation episodes on subsequent inflation below).

As discussed in the introduction, crises may also affect political developments and the quality of institutions. In particular, the adverse economic effects of crises may translate into a political backlash against economic reform and increased support for populist and authoritarian-minded parties (see Fidrmuc, 2000 a,b; Jackson, Klich and Poznańska, 2001; Tucker, 2002). This is in line with the stylized facts cited by Przeworski (2005) who observes that democracies tend to be very fragile and vulnerable to regime change in relatively poor countries (see also Hellman, 1998). Given that most post-communist countries were relatively poor at the time they initiated their economic reforms, it is indeed possible that the severity of the crises they experienced could account for the (partial) reversals of political reform that some of them undertook: the most notable examples are Belarus and Turkmenistan; Russia likewise has reverted to (moderately) authoritarian rule during the Putin-Medvedev era.

In Table 7, we therefore consider the impact of past crises on democratization as measured by the average of indexes of political freedoms and civil liberties reported by the Freedom House. The dependent variable is the first difference of this measure and the regressions control also for the lagged level of democracy. Since we found earlier that crises translate into faster economic reform and that democratization also correlates with economic reform, we could expect a positive effect. In contrast, the discussion in the preceding paragraph would suggest that the effect should be negative rather than positive. The regression results support the latter prediction: the deeper the crisis, the slower the subsequent democratization process. This effect is robust to including GDP per capita (which has a positive, although not always significant, effect on democratization) and inflation (which slows down democratization) as well as other variables. Hence, crises discourage democratization and this effect goes beyond to what can be ascribed to the transition-induced recession and inflation. We again allow the effect to vary over time but the interaction terms are not significant. ${ }^{11}$

To further explore the effect of crises on institutional quality, we use the governance indicators constructed by Kaufmann, Kraay and Mastruzzi (2009). Kaufmann et al. aggregate information from a host of other sources on the quality of institutions in six areas: control of corruption, voice and accountability, political stability, government effectiveness, regulatory quality, and rule of law. The indicators are constructed so that higher values always correspond to better institutions. Their coverage, however, is limited: the indicators are available at semi-annual frequency from 1996 to 2000 and then annually from 2002. Because of this, we are unable to use lags of these variables: we therefore use lags of both economic reform (EBRD) and democracy (Freedom House) indexes instead (Table 8). ${ }^{12}$ Both of these

\footnotetext{
11 Nevertheless, when we introduce a quadratic term of the output fall to allow for nonlinearity. we find a Ushaped effect, with the minimum attained for output fall reaching 39.5 percent (results available upon request).

12 Note that as the indicators are not available before 1996, the early transition period is dropped from the analysis.
} 
indexes are positive; the effect of economic reform is always strongly significant while that of democracy is significantly positive in three regressions out of six. There are thus important spillovers from economic policy and democratization to institutional quality. The effect of past crises, however, is never significant. Yet, the time-varying effect is U-shaped, with the quadratic term always significant. This implies that although past crises may initially lead to a worsening of institutions in the short term, this is followed by an improvement later on: when it comes to crises, good things come to those who wait.

Finally, economic crises tend to be manifested not only in output contractions but also in high inflation. We therefore replace the output-fall measure of crises with the cumulative inflation. All regressions, reported in Table 9, again control for the level of the reform index (which is not consistently significant) and for being involved in a military conflict (not surprisingly, wars are associated with much higher inflation). We also include the output fall and GDP per capita: neither appears significant as a determinant of inflation. However, cumulative inflation is significantly negative in every regression: having a legacy of high inflation in the past exerts a negative effect on subsequent price growth. This stands in contrast with the insignificant effect of output fall: when it comes to inflation, countries learn a lesson from past high-inflation episodes but not from recessions.

\section{Conclusions}

In this paper, we investigate the effect of crises on economic reforms, economic performance, democratization and institutional change. To this effect, we utilize the experience of the postcommunist countries, virtually all of which experienced crises (extraordinarily severe crises in some cases) following the demise of communism and central planning in the early 1990s. Our results suggest that crises indeed serve as a catalyst for reforms: history of having experienced a crisis in the past is associated with greater economic reform and better institutions (although the institutional improvement only occurs with a delay). Crises also translate into better economic performance: they are followed by higher growth, lower inflation and, with a delay, higher investment. Our results thus offer support for the 'crises beget reform' hypothesis put forward by Alesina and Drazen (1991). Importantly, they suggest that the favorable effect of crises goes beyond accelerating economic reform: there are also positive repercussions for economic performance, political reform and institutional change. 


\section{References}

Alesina, A., Drazen, A. 1991. Why are stabilizations delayed? American Economic Review $81(5), 1170-1188$.

Alesina, A., Ardagna, S., Trebbi, F., 2006. Who Adjusts and When? The Political Economy of Reforms, IMF Staff Papers 53 (Special Issue), 1-29.

Arrow, K.J., 2000. Increasing Returns. Hitoriographic Issues and Path Dependence. European Journal of the History of Economic Thought 7, 171-180.

Aslund, Anders, Peter Boone and Simon Johnson, 1996. How to Stabilize: Lessons from Postcommunist Countries, Brookings Papers on Economic Activity 1, 217-291.

Bruno, M., Easterly, W., 1996. Inflation's Children: Tales of Crises That Beget Reforms, American Economic Review (Papers and Proceedings) 86 (2), 213-217.

Bruno, M. and W. Easterly, 1996. Inflation Crises and Long-run Growth, Journal of Monetary Economics 41, 3-26.

Cavallo, A.F. and E.A. Cavallo (2010), "Are crises good for long-term growth? The role of political institutions," Journal of Macroeconomics 32, 838-857.0020

Drazen, A. and W. Easterly, 2001, Do crisis induce reform? Simple empirical test of conventional wisdom. Economics and politics 13, 129-157.

Fernandez, Raquel, and Dani Rodrik, 1991. Resistance to Reform: Status-quo Bias in the Presence of Individual-Specific Uncertainty, American Economic Review 81 (5), 11461155.

Fidrmuc, Jan, 2000a. Political Support for Reforms: Economics of Voting in Transition Countries, European Economic Review 44 (8), 1491-1513.

Fidrmuc, Jan, 2000b. Economics of Voting in Post-Communist Countries, Electoral Studies 19 (2/3), Special issue: Economics and Elections, June/September 2000, 199-217.

Fidrmuc, Jan, 2003. Economic Reform, Democracy and Growth during Post-communist Transition, European Journal of Political Economy 19 (3), 583-604.

Hellman, J.S., 1998. Winners take all: The politics of partial reform in post-communist transitions," World Politics 50 (January), 203-234.

Heybey, B. and P.Murrell, 1999. The Relationship between Economic Growth and the Speed of Liberalization During Transition. Policy Reform 3, 121-137.

Jackson, John E., Jacek Klich and Krystyna Poznańska, 2001. Economic Transition and Elections in Poland. William Davidson Working Paper No. 391.

Kaufmann, D., A. Kraay and M. Mastruzzi, 2009. Governance Matters VIII: Aggregate and Individual Governance Indicators 1996-2008, Policy Research Working Paper 4978, The World Bank.

Kornai, J. (1994), “Transformational Recession: The Main Causes," Journal of Comparative Economics 19 (1), 39-63.

Krueger, A.O., 1993. Virtuous and Vicious Circles in Economic Development, American Economic Review (Papers and Proceedings) 83 (2), 351-355.

Lora, E. and M. Olivera (2004), "What Makes Reforms Likely: Political Economy Determinants of Reforms in Latin America," Journal of Applied Economics 7(1), 99-135. 
Magnusson, L., and J. Ottoson, 1997. Evolutionary Economics and Path Dependence, Cheltenham, Brookfield.

Pitlik, H., 2011. When Do Crises Induce Market-oriented Reform? Austrian Institute of Economic Research (WIFO), mimeo.

Pitlik, H., Wirth, S., 2003. Do crises promote the extent of economic liberalization? An empirical test. European Journal of Political Economy 19, 565-581.

Przeworski, A. (2005), "Democracy as an equilibrium,” Public Choice 123, 253-273.

Rodrik, Dani, 1995. The Dynamics of Political Support for Reforms in Economies in Transition, Journal of the Japanese and International Economies 9 (4), 403-425.

Roland, G, 2000. Transition and economics: Politics, markets, and firms, MIT Press, Cambridge, Massachusetts.

Sarkees, Meredith Reid and Frank Wayman, 2010. Resort to War: 1816 - 2007. CQ Press

Tucker, Joshua A., 2002. The First Decade of Post-communist Elections and Voting: What Have We Studied, and How Have We Studied It? Annual Review of Political Science 5, 271-304.

Zweynert, J., and N. Goldschmidt, 2005. The Two Transitions in Central and Eastern Europe and the Relation between Path Dependent and politically Implemented Institutional Change. HWWA Discussion Paper 314. 
Table 1 Output Fall and Progress in Market-oriented Reform

\begin{tabular}{|c|c|c|c|c|c|}
\hline \multirow[t]{2}{*}{ Dependent variable: } & \multicolumn{5}{|c|}{ EBRD index (first difference) } \\
\hline & (1) & (2) & (3) & (4) & (5) \\
\hline \multirow[t]{2}{*}{$\begin{array}{l}\text { Lagged EBRD } \\
\text { index }\end{array}$} & -0.278 & -0.185 & -0.302 & -0.277 & -0.297 \\
\hline & $(0.014)^{\star \star}$ & $(0.012)^{\star \star}$ & $(0.017)^{\star \star}$ & $(0.019)^{\star \star}$ & $(0.022)^{\star \star}$ \\
\hline \multirow[t]{2}{*}{ Lagged Democracy } & 0.079 & 0.059 & 0.077 & 0.065 & 0.063 \\
\hline & $(0.008)^{\star \star}$ & $(0.008)^{\star \star}$ & $(0.008)^{\star \star}$ & $(0.009)^{\star \star}$ & $(0.009)^{\star *}$ \\
\hline \multirow[t]{2}{*}{ War } & -0.085 & -0.108 & -0.064 & -0.104 & -0.087 \\
\hline & $(0.027)^{\star \star}$ & $(0.032)^{\star \star}$ & $(0.030)^{\star}$ & $(0.031)^{\star \star}$ & $(0.032)^{\star \star}$ \\
\hline \multirow[t]{2}{*}{ Lagged outputfall } & 0.006 & & 0.007 & 0.006 & 0.005 \\
\hline & $(0.001)^{\star \star}$ & & $(0.001)^{\star \star}$ & $(0.001)^{\star \star}$ & $(0.001)^{\star \star}$ \\
\hline \multirow{2}{*}{$\begin{array}{l}\text { Lagged gdp p.c. } \\
\text { (thousands) }\end{array}$} & & -0.013 & 0.005 & 0.008 & -0.006 \\
\hline & & $(0.004)^{\star \star}$ & $(0.004)$ & $(0.004)^{\star}$ & $(0.006)$ \\
\hline \multirow[t]{2}{*}{ Lagged inflation } & & & & 0.013 & 0.019 \\
\hline & & & & $(0.004)^{\star \star}$ & $(0.005)^{\star \star}$ \\
\hline \multirow[t]{2}{*}{ Outputfall*time } & & & & & 0.0001 \\
\hline & & & & & $(0.0002)$ \\
\hline \multirow[t]{2}{*}{${\text { Outputfall }{ }^{\star} \text { time }}^{2}$} & & & & & $-5.96 e-06$ \\
\hline & & & & & $(1.68 \mathrm{e}-05)$ \\
\hline \multirow[t]{2}{*}{ Time after crisis } & & & & & 0.004 \\
\hline & & & & & $(0.011)$ \\
\hline \multirow[t]{2}{*}{ Time after crisis ${ }^{2}$} & & & & & 0.000 \\
\hline & & & & & $(0.001)$ \\
\hline \multirow[t]{2}{*}{ Constant } & 0.265 & 0.421 & 0.241 & 0.23 & 0.358 \\
\hline & $(0.031)^{\star \star}$ & $(0.038)^{\star \star}$ & $(0.040)^{\star \star}$ & $(0.049)^{\star \star}$ & $(0.064)^{\star \star}$ \\
\hline $\begin{array}{l}\text { Observations } \\
\text { Number of }\end{array}$ & 550 & 524 & 524 & 495 & 495 \\
\hline Countries & 29 & 29 & 29 & 29 & 29 \\
\hline R-squared & 0.45 & 0.39 & 0.48 & 0.5 & 0.52 \\
\hline
\end{tabular}

All regressions include country-specific fixed effects. Standard errors in parentheses.

Significance: ${ }^{*} 5 \%$; $* * 1 \%$ 
Table 2 Output Fall and Sub-indexes of Progress in Market-oriented Reform

\begin{tabular}{|c|c|c|c|c|c|c|c|c|}
\hline Dependent variable: & $\begin{array}{c}\text { Large-scale } \\
\text { Privatization } \\
\text { (1) }\end{array}$ & $\begin{array}{c}\text { Small-scale } \\
\text { Privatization } \\
\text { (2) }\end{array}$ & $\begin{array}{c}\text { Enterprise } \\
\text { Reform } \\
\text { (3) }\end{array}$ & $\begin{array}{c}\text { Price } \\
\text { Controls } \\
(4)\end{array}$ & $\begin{array}{l}\text { Foreign } \\
\text { Trade } \\
\text { (5) }\end{array}$ & $\begin{array}{c}\text { Competition } \\
\text { Policy } \\
(6)\end{array}$ & $\begin{array}{c}\text { Banking } \\
(7)\end{array}$ & $\begin{array}{c}\text { Security } \\
\text { Markets } \\
\text { (8) }\end{array}$ \\
\hline $\begin{array}{l}\text { Lagged EBRD } \\
\text { sub-index }\end{array}$ & $\begin{array}{c}-0.241 \\
(0.025)^{\star \star}\end{array}$ & $\begin{array}{c}-0.309 \\
(0.022)^{\star \star}\end{array}$ & $\begin{array}{c}-0.402 \\
(0.030)^{\star \star}\end{array}$ & $\begin{array}{c}-0.524 \\
(0.034)^{\star \star}\end{array}$ & $\begin{array}{c}-0.392 \\
(0.028)^{\star \star}\end{array}$ & $\begin{array}{c}-0.286 \\
(0.029)^{\star \star}\end{array}$ & $\begin{array}{c}-0.316 \\
(0.030)^{\star \star}\end{array}$ & $\begin{array}{c}-0.270 \\
(0.028)^{\star \star}\end{array}$ \\
\hline Lagged Democracy & $\begin{array}{c}0.073 \\
(0.017)^{\star \star}\end{array}$ & $\begin{array}{c}0.089 \\
(0.015)^{\star \star}\end{array}$ & $\begin{array}{c}0.102 \\
(0.014)^{\star *}\end{array}$ & $\begin{array}{c}0.077 \\
(0.020)^{\star \star}\end{array}$ & $\begin{array}{c}0.079 \\
(0.020)^{\star \star}\end{array}$ & $\begin{array}{c}0.060 \\
(0.012)^{\star \star}\end{array}$ & $\begin{array}{c}0.095 \\
(0.016)^{\star \star}\end{array}$ & $\begin{array}{c}0.057 \\
(0.013)^{\star *}\end{array}$ \\
\hline War & $\begin{array}{l}-0.127 \\
(0.064)^{\star}\end{array}$ & $\begin{array}{l}-0.087 \\
(0.060)\end{array}$ & $\begin{array}{c}-0.137 \\
(0.052)^{\star \star}\end{array}$ & $\begin{array}{l}-0.016 \\
(0.081)\end{array}$ & $\begin{array}{c}-0.264 \\
(0.076)^{\star \star}\end{array}$ & $\begin{array}{l}-0.050 \\
(0.051)\end{array}$ & $\begin{array}{l}-0.110 \\
(0.058)\end{array}$ & $\begin{array}{c}0.022 \\
(0.053)\end{array}$ \\
\hline Lagged outputfall & $\begin{array}{c}0.006 \\
(0.001)^{\star \star}\end{array}$ & $\begin{array}{c}0.011 \\
(0.002)^{\star \star}\end{array}$ & $\begin{array}{c}0.008 \\
(0.001)^{\star \star}\end{array}$ & $\begin{array}{c}0.013 \\
(0.002)^{\star \star}\end{array}$ & $\begin{array}{c}0.013 \\
(0.002)^{\star \star}\end{array}$ & $\begin{array}{c}0.005 \\
(0.001)^{\star \star}\end{array}$ & $\begin{array}{c}0.009 \\
(0.001)^{\star \star}\end{array}$ & $\begin{array}{c}0.005 \\
(0.001)^{\star *}\end{array}$ \\
\hline $\begin{array}{l}\text { Lagged gdp p.c. } \\
\text { (thousands) }\end{array}$ & $\begin{array}{l}-0.005 \\
(0.007)\end{array}$ & $\begin{array}{l}-0.006 \\
(0.007)\end{array}$ & $\begin{array}{c}0.017 \\
(0.006)^{\star \star}\end{array}$ & $\begin{array}{c}0.015 \\
(0.009)\end{array}$ & $\begin{array}{c}0.006 \\
(0.009)\end{array}$ & $\begin{array}{c}0.022 \\
(0.006)^{\star \star}\end{array}$ & $\begin{array}{c}0.022 \\
(0.007)^{\star \star}\end{array}$ & $\begin{array}{c}0.018 \\
(0.007)^{\star \star}\end{array}$ \\
\hline Lagged inflation & $\begin{array}{c}0.005 \\
(0.008)\end{array}$ & $\begin{array}{c}0.018 \\
(0.007)^{\star}\end{array}$ & $\begin{array}{c}0.007 \\
(0.006)\end{array}$ & $\begin{array}{c}0.037 \\
(0.009)^{\star \star}\end{array}$ & $\begin{array}{c}0.002 \\
(0.010)\end{array}$ & $\begin{array}{c}0.007 \\
(0.006)\end{array}$ & $\begin{array}{c}0.008 \\
(0.007)\end{array}$ & $\begin{array}{l}-0.008 \\
(0.006)\end{array}$ \\
\hline Constant & $\begin{array}{c}0.194 \\
(0.102)\end{array}$ & $\begin{array}{c}0.349 \\
(0.095)^{\star \star}\end{array}$ & $\begin{array}{l}-0.002 \\
(0.082)\end{array}$ & $\begin{array}{c}0.977 \\
(0.130)^{\star \star}\end{array}$ & $\begin{array}{c}0.547 \\
(0.121)^{\star \star}\end{array}$ & $\begin{array}{c}0.009 \\
(0.080)\end{array}$ & $\begin{array}{l}-0.099 \\
(0.093) \\
\end{array}$ & $\begin{array}{c}0.044 \\
(0.083)\end{array}$ \\
\hline $\begin{array}{c}\text { Observations } \\
\text { Number of } \\
\text { Countries }\end{array}$ & $\begin{array}{l}495 \\
29\end{array}$ & $\begin{array}{l}495 \\
29\end{array}$ & $\begin{array}{l}495 \\
29\end{array}$ & $\begin{array}{l}495 \\
29\end{array}$ & $\begin{array}{l}495 \\
29\end{array}$ & $\begin{array}{l}495 \\
29\end{array}$ & 495 & $\begin{array}{l}495 \\
29\end{array}$ \\
\hline R-squared & 0.27 & 0.43 & 0.35 & 0.45 & 0.38 & 0.21 & 0.28 & 0.19 \\
\hline
\end{tabular}

All regressions include country-specific fixed effects. Standard errors in parentheses. Lagged EBRD sub-index is the same index as that denoted in the column heading. Significance: ${ }^{*} 5 \%$; ${ }^{* *} 1 \%$ 
Table 3 Output Fall and Economic Growth

\begin{tabular}{|c|c|c|c|c|c|}
\hline \multirow[t]{2}{*}{ Dependent variable: } & \multicolumn{5}{|c|}{ GDP p.c. growth rate } \\
\hline & $(1)$ & $(2)$ & (3) & $(4)$ & (5) \\
\hline \multirow[t]{2}{*}{ Lagged EBRD index } & 4.031 & 7.612 & 4.158 & 2.273 & 1.804 \\
\hline & $(0.725)^{\star \star}$ & $(0.520)^{\star \star}$ & $(0.854)^{\star \star}$ & $(0.731)^{\star \star}$ & $(0.880)^{x}$ \\
\hline \multirow[t]{2}{*}{ Lagged Investment } & 0.009 & -0.063 & 0.018 & -0.017 & -0.018 \\
\hline & (0.058) & $(0.057)$ & (0.058) & $(0.044)$ & $(0.046)$ \\
\hline \multirow[t]{2}{*}{ War } & -12.359 & -14.932 & -12.957 & -9.455 & -8.251 \\
\hline & $(1.717)^{\star \star}$ & $(1.752)^{\star \star}$ & $(1.753)^{\star \star}$ & $(1.334)^{\star \star}$ & $(1.359)^{\star \star}$ \\
\hline \multirow[t]{2}{*}{ Lagged outputfall } & 0.246 & & 0.248 & 0.327 & 0.259 \\
\hline & $(0.043)^{\star \star}$ & & $(0.049)^{\star \star}$ & $(0.040)^{\star \star}$ & $(0.042)^{\star \star}$ \\
\hline \multirow{2}{*}{$\begin{array}{l}\text { Lagged gdp p.c. } \\
\text { (thousands) }\end{array}$} & & -0.613 & -0.134 & -0.259 & -0.480 \\
\hline & & $(0.182)^{\star \star}$ & $(0.201)$ & $(0.149)$ & $(0.233)^{*}$ \\
\hline \multirow[t]{2}{*}{ Lagged inflation } & & & & -1.404 & -1.001 \\
\hline & & & & $(0.162)^{\star \star}$ & $(0.185)^{\star \star}$ \\
\hline \multirow[t]{2}{*}{ Time*outputfall } & & & & & 0.027 \\
\hline & & & & & $(0.010)^{\star \star}$ \\
\hline \multirow[t]{2}{*}{ Time ${ }^{2 *}$ outputfall } & & & & & -0.002 \\
\hline & & & & & $(0.001)^{x}$ \\
\hline \multirow[t]{2}{*}{ Time after crisis } & & & & & -0.239 \\
\hline & & & & & $(0.424)$ \\
\hline \multirow[t]{2}{*}{ Time after crisis ${ }^{2}$} & & & & & 0.023 \\
\hline & & & & & $(0.027)$ \\
\hline \multirow[t]{2}{*}{ Constant } & -16.473 & -10.567 & -16.062 & -8.709 & -7.236 \\
\hline & $(1.819)^{\star \star}$ & $(1.849)^{\star \star}$ & $(2.109)^{\star \star}$ & $(1.932)^{\star \star}$ & $(2.536)^{\star \star}$ \\
\hline Observations & 505 & 503 & 503 & 479 & 479 \\
\hline Number of Countries & 29 & 29 & 29 & 29 & 29 \\
\hline R-squared & 0.49 & 0.46 & 0.49 & 0.67 & 0.69 \\
\hline
\end{tabular}

All regressions include country-specific fixed effects. Standard errors in parentheses.

Significance: ${ }^{*} 5 \% ; * * 1 \%$ 
Table 4 Output Fall and Investment

\begin{tabular}{|c|c|c|c|c|c|}
\hline \multirow[t]{2}{*}{ Dependent variable } & \multicolumn{5}{|c|}{ Investment } \\
\hline & $(1)$ & $(2)$ & (3) & $(4)$ & $(5)$ \\
\hline \multirow[t]{2}{*}{ Lagged EBRDindex } & 4.246 & 1.808 & 4.242 & 5.018 & 6.681 \\
\hline & $(0.516)^{\star \star}$ & $(0.401)^{\star \star}$ & $(0.643)^{\star \star}$ & $(0.752)^{\star \star}$ & $(0.852)^{\star \star}$ \\
\hline \multirow[t]{2}{*}{ War } & -4.086 & -3.383 & -4.386 & -4.333 & -1.949 \\
\hline & $(1.283)^{\star \star}$ & $(1.344)^{\star}$ & $(1.331)^{\star \star}$ & $(1.420)^{\star \star}$ & (1.390) \\
\hline \multirow[t]{2}{*}{ Lagged outputfall } & -0.171 & & -0.171 & -0.182 & -0.205 \\
\hline & $(0.028)^{\star \star}$ & & $(0.036)^{\star \star}$ & $(0.041)^{\star \star}$ & $(0.042)^{\star \star}$ \\
\hline \multirow{2}{*}{$\begin{array}{l}\text { Lagged gdp p.c. } \\
\text { (thousands) }\end{array}$} & & 0.562 & 0.148 & 0.115 & 0.021 \\
\hline & & $(0.142)^{\star \star}$ & $(0.164)$ & $(0.164)$ & $(0.243)$ \\
\hline \multirow[t]{2}{*}{ Lagged inflation } & & & & 0.123 & -0.025 \\
\hline & & & & $(0.174)$ & $(0.190)$ \\
\hline \multirow[t]{2}{*}{ outputfall ${ }^{\star}$ time } & & & & & 0.030 \\
\hline & & & & & $(0.010)^{\star \star}$ \\
\hline \multirow[t]{2}{*}{ outputfall*time ${ }^{2}$} & & & & & -0.001 \\
\hline & & & & & $(0.001)$ \\
\hline \multirow[t]{2}{*}{ Time after crisis } & & & & & -2.254 \\
\hline & & & & & $(0.430)^{\star \star}$ \\
\hline \multirow[t]{2}{*}{ Time after crisis ${ }^{2}$} & & & & & 0.102 \\
\hline & & & & & $(0.027)^{\star \star}$ \\
\hline \multirow[t]{2}{*}{ Constant } & 18.014 & 13.921 & 16.948 & 14.972 & 14.752 \\
\hline & $(0.981)^{\star \star}$ & $(1.271)^{\star \star}$ & $(1.396)^{\star \star}$ & $(1.909)^{\star \star}$ & $(2.492)^{\star \star}$ \\
\hline Observations & 520 & 508 & 508 & 481 & 481 \\
\hline Number of Countries & 29 & 29 & 29 & 29 & 29 \\
\hline R-squared & 0.15 & 0.12 & 0.16 & 0.19 & 0.29 \\
\hline
\end{tabular}

All regressions include country-specific fixed effects. Standard errors in parentheses.

Significance: * $5 \%$; ${ }^{*} 1 \%$ 
Table 5 Output Fall and Foreign Direct Investment Inflow

\begin{tabular}{|c|c|c|c|c|c|}
\hline \multirow[t]{2}{*}{ Dependent variable: } & \multicolumn{5}{|c|}{ Foreign Direct Investment } \\
\hline & (1) & (2) & (3) & (4) & (5) \\
\hline \multirow[t]{2}{*}{ Lagged EBRD index } & 5.266 & 0.418 & 5.840 & 3.409 & 2.243 \\
\hline & $(1.778)^{\star \star}$ & (1.650) & $(2.229)^{\star \star}$ & (2.758) & (3.249) \\
\hline \multirow[t]{2}{*}{ War } & 11.273 & 17.804 & 13.285 & 14.052 & 14.632 \\
\hline & $(4.439)^{\star}$ & $(4.487)^{\star \star}$ & $(4.607)^{\star *}$ & $(4.952)^{\star \star}$ & $(5.215)^{\star \star}$ \\
\hline \multirow[t]{2}{*}{ Lagged outputfall } & -0.456 & & -0.523 & -0.527 & -0.581 \\
\hline & $(0.123)^{\star \star}$ & & $(0.147)^{\star \star}$ & $(0.154)^{\star \star}$ & $(0.162)^{\star \star}$ \\
\hline \multirow{2}{*}{$\begin{array}{l}\text { Lagged gdp p.c. } \\
\text { (thousands) }\end{array}$} & & 0.721 & -0.023 & -0.096 & -0.944 \\
\hline & & $(0.459)$ & $(0.499)$ & $(0.518)$ & $(0.824)$ \\
\hline \multirow[t]{2}{*}{ Lagged inflation } & & & & -0.995 & -0.580 \\
\hline & & & & $(0.619)$ & $(0.727)$ \\
\hline \multirow[t]{2}{*}{ Outputfall*time } & & & & & 0.028 \\
\hline & & & & & $(0.035)$ \\
\hline \multirow[t]{2}{*}{ Outputfall $\star$ time $^{2}$} & & & & & -0.002 \\
\hline & & & & & $(0.002)$ \\
\hline \multirow[t]{2}{*}{ Time after crisis } & & & & & -0.428 \\
\hline & & & & & $(1.518)$ \\
\hline \multirow[t]{2}{*}{ Time after crisis ${ }^{2}$} & & & & & 0.088 \\
\hline & & & & & $(0.095)$ \\
\hline \multirow[t]{2}{*}{ Constant } & 8.692 & -1.327 & 9.772 & 19.631 & 25.971 \\
\hline & $(4.492)$ & $(4.336)$ & $(5.295)$ & $(7.982)^{\star}$ & $(9.875)^{\star \star}$ \\
\hline Observations & 477 & 472 & 472 & 454 & 454 \\
\hline Number of Countries & 29 & 29 & 29 & 29 & 29 \\
\hline R-squared & 0.07 & 0.04 & 0.07 & 0.08 & 0.08 \\
\hline
\end{tabular}

All regressions include country-specific fixed effects. Standard errors in parentheses.

Significance: * $5 \%$; ${ }^{* *} 1 \%$ 
Table 6 Output Fall and Inflation

\begin{tabular}{|c|c|c|c|c|}
\hline \multirow[t]{2}{*}{ Dependent variable: } & \multicolumn{4}{|c|}{ Inflation } \\
\hline & $(1)$ & (2) & (3) & (4) \\
\hline \multirow[t]{2}{*}{ Lagged EBRD index } & 4.104 & 51.012 & 139.601 & $1,060.744$ \\
\hline & $(461.71)$ & (393.82) & $(586.14)$ & $(742.235)$ \\
\hline \multirow[t]{2}{*}{ War } & $4,552.84$ & $5,083.95$ & $5,040.40$ & $4,149.849$ \\
\hline & $(1,126.2)^{\star \star}$ & $(1,172.3)^{\star \star}$ & $(1,192.7)^{\star \star}$ & $(1,268.049)^{\star \star}$ \\
\hline \multirow[t]{2}{*}{ Lagged outputfall } & 4.308 & & -6.22 & 24.121 \\
\hline & (24.06) & & (30.46) & (33.539) \\
\hline \multirow{2}{*}{$\begin{array}{l}\text { Lagged Gdp p.c. } \\
\text { (thousands) }\end{array}$} & & -8.138 & -23.865 & 253.472 \\
\hline & & (128.2) & $(149.66)$ & $(231.440)$ \\
\hline \multirow[t]{2}{*}{ Outputfall^time } & & & & -7.128 \\
\hline & & & & (9.560) \\
\hline \multirow[t]{2}{*}{${\text { Outputfall}{ }^{\star} \text { time }^{2}}^{2}$} & & & & 0.362 \\
\hline & & & & $(0.657)$ \\
\hline \multirow[t]{2}{*}{ Time after crisis } & & & & -183.630 \\
\hline & & & & $(428.574)$ \\
\hline \multirow[t]{2}{*}{ Time after crisis ${ }^{2}$} & & & & 0.673 \\
\hline & & & & $(27.677)$ \\
\hline \multirow[t]{2}{*}{ Constant } & -21.855 & 73.299 & 189.697 & $-3,442.930$ \\
\hline & $(944.906)$ & $(1,181.98)$ & $(1,313.27)$ & $(2,236.885)$ \\
\hline Observations & 524 & 512 & 512 & 512 \\
\hline Number of Countries & 29 & 29 & 29 & 29 \\
\hline R-squared & 0.04 & 0.04 & 0.04 & 0.06 \\
\hline
\end{tabular}


Table 7 Output Fall and Democratization

\begin{tabular}{|c|c|c|c|c|c|}
\hline \multirow[t]{2}{*}{ Dependent variable: } & \multicolumn{5}{|c|}{ Democracy (first difference) } \\
\hline & (1) & $(2)$ & $(3)$ & (4) & (5) \\
\hline \multirow[t]{2}{*}{ Lagged democracy } & -0.343 & -0.376 & -0.358 & -0.366 & -0.373 \\
\hline & $(0.021)^{\star \star}$ & $(0.022)^{\star \star}$ & $(0.022)^{\star \star}$ & $(0.024)^{\star \star}$ & $(0.025)^{\star *}$ \\
\hline \multirow[t]{2}{*}{ Lagged output fall } & -0.005 & & -0.006 & -0.005 & -0.007 \\
\hline & $(0.001)^{\star \star}$ & & $(0.002)^{\star \star}$ & $(0.002)^{\star \star}$ & $(0.003)^{\star}$ \\
\hline \multirow[t]{2}{*}{ War } & -0.551 & -0.397 & -0.507 & -0.381 & -0.322 \\
\hline & $(0.089)^{\star \star}$ & $(0.092)^{\star \star}$ & $(0.095)^{\star \star}$ & $(0.100)^{\star \star}$ & $(0.104)^{\star \star}$ \\
\hline \multirow{2}{*}{$\begin{array}{l}\text { Lagged gdp p.c. } \\
\text { (thousands) }\end{array}$} & & 0.032 & 0.023 & 0.008 & -0.011 \\
\hline & & $(0.010)^{\star \star}$ & $(0.010)^{*}$ & $(0.011)$ & $(0.019)$ \\
\hline \multirow[t]{2}{*}{ Lagged inflation } & & & & -0.035 & -0.034 \\
\hline & & & & $(0.011)^{\star *}$ & $(0.014)^{\star}$ \\
\hline \multirow{2}{*}{ Outputfall*time } & & & & & 0.001 \\
\hline & & & & & $(0.001)$ \\
\hline \multirow{2}{*}{ Outputfall ${ }^{\star}$ time ${ }^{2}$} & & & & & -0.0001 \\
\hline & & & & & $(0.0001)$ \\
\hline \multirow{2}{*}{ Time after crisis } & & & & & -0.062 \\
\hline & & & & & $(0.031)^{\star}$ \\
\hline \multirow[t]{2}{*}{ Time after crisis ${ }^{2}$} & & & & & 0.004 \\
\hline & & & & & $(0.002)^{\star}$ \\
\hline \multirow[t]{2}{*}{ Constant } & 1.810 & 1.538 & 1.759 & 1.966 & 2.158 \\
\hline & $(0.101)^{* *}$ & $(0.110)^{\star \star}$ & $(0.123)^{\star \star}$ & $(0.157)^{\star *}$ & $(0.206)^{\star \star}$ \\
\hline Observations & 551 & 525 & 525 & 496 & 496 \\
\hline Number of Countries & 29 & 29 & 29 & 29 & 29 \\
\hline R-squared & 0.37 & 0.38 & 0.40 & 0.37 & 0.38 \\
\hline
\end{tabular}

All regressions include country-specific fixed effects. Standard errors in parentheses.

Significance: $* 5 \% ; * * 1 \%$ 
Table 8 Output Fall and Quality of institutions

\begin{tabular}{|c|c|c|c|c|c|c|}
\hline Dependent variable: & $\begin{array}{c}\text { Control of } \\
\text { Corruption } \\
\\
(1)\end{array}$ & $\begin{array}{l}\text { Voice and } \\
\text { Account- } \\
\text { ability } \\
(2)\end{array}$ & $\begin{array}{c}\text { Political } \\
\text { Stability } \\
\text { (3) }\end{array}$ & $\begin{array}{c}\text { Gov } \\
\text { Effective- } \\
\text { ness } \\
(4)\end{array}$ & $\begin{array}{l}\text { Regulatory } \\
\text { Quality } \\
\text { (5) }\end{array}$ & $\begin{array}{c}\text { Rule of } \\
\text { Law } \\
(6)\end{array}$ \\
\hline Lagged EBRD index & $\begin{array}{r}0.155 \\
(0.085)\end{array}$ & $\begin{array}{r}0.192 \\
(0.076)^{\star \star}\end{array}$ & $\begin{array}{r}0.340 \\
(0.127)^{\star \star}\end{array}$ & $\begin{array}{r}0.313 \\
(0.078)^{\star \star}\end{array}$ & $\begin{array}{r}0.270 \\
(0.086)^{\star \star}\end{array}$ & $\begin{array}{r}0.144 \\
(0.068)^{\star}\end{array}$ \\
\hline Lagged democracy & $\begin{array}{r}0.103 \\
(0.026)^{\star \star}\end{array}$ & $\begin{array}{r}0.214 \\
(0.023)^{\star \star}\end{array}$ & $\begin{array}{r}0.027 \\
(0.039)\end{array}$ & $\begin{array}{r}0.039 \\
(0.024)\end{array}$ & $\begin{array}{r}0.014 \\
(0.027)\end{array}$ & $\begin{array}{r}0.068 \\
(0.021)^{\star \star}\end{array}$ \\
\hline Lagged output fall & $\begin{array}{r}-0.006 \\
(0.014)\end{array}$ & $\begin{array}{l}-0.015 \\
(0.013)\end{array}$ & $\begin{array}{r}0.012 \\
(0.021)\end{array}$ & $\begin{array}{l}-0.009 \\
(0.013)\end{array}$ & $\begin{array}{r}0.004 \\
(0.014)\end{array}$ & $\begin{array}{r}-0.021 \\
(0.011)\end{array}$ \\
\hline War & $\begin{array}{l}-0.002 \\
(0.204)\end{array}$ & $\begin{array}{l}-0.183 \\
(0.182)\end{array}$ & $\begin{array}{r}-1.069 \\
(0.304)^{\star *}\end{array}$ & $\begin{array}{r}-0.148 \\
(0.189)\end{array}$ & $\begin{array}{r}-0.812 \\
(0.206)^{\star \star}\end{array}$ & $\begin{array}{l}-0.198 \\
(0.164)\end{array}$ \\
\hline $\begin{array}{l}\text { Lagged gdp p.c. } \\
\text { (thousands) }\end{array}$ & $\begin{array}{r}0.038 \\
(0.011)\end{array}$ & $\begin{array}{l}-0.018 \\
(0.010)\end{array}$ & $\begin{array}{r}0.033 \\
(0.017)^{\star}\end{array}$ & $\begin{array}{r}0.032 \\
(0.011)^{\star \star}\end{array}$ & $\begin{array}{r}-0.016 \\
(0.011)\end{array}$ & $\begin{array}{r}0.052 \\
(0.009)^{\star *}\end{array}$ \\
\hline $\begin{array}{l}\text { Lagged inflation } \\
(\log )\end{array}$ & $\begin{array}{r}-0.052 \\
(0.012)\end{array}$ & $\begin{array}{r}-0.010 \\
(.010)\end{array}$ & $\begin{array}{r}0.032 \\
(0.017)\end{array}$ & $\begin{array}{r}-0.007 \\
(0.011)\end{array}$ & $\begin{array}{l}-0.013 \\
(0.011)\end{array}$ & $\begin{array}{l}-0.004 \\
(0.009)\end{array}$ \\
\hline Outputfall*time & $\begin{array}{r}-0.0013 \\
(0.0006)^{*}\end{array}$ & $\begin{array}{r}-0.0009 \\
(0.0005)\end{array}$ & $\begin{array}{r}-0.0008 \\
(0.0009)\end{array}$ & $\begin{array}{r}-0.0020 \\
(0.0006)^{\star \star}\end{array}$ & $\begin{array}{l}-0.0011 \\
(0.0006)\end{array}$ & $\begin{array}{r}-0.0006 \\
(0.0004)\end{array}$ \\
\hline${\text { Outputfall }{ }^{*} \text { time }}^{2}$ & $\begin{array}{r}0.0001 \\
(0.0000)^{\star \star}\end{array}$ & $\begin{array}{r}0.0001 \\
(0.0000)^{*}\end{array}$ & $\begin{array}{r}0.0001 \\
(0.0000)^{*}\end{array}$ & $\begin{array}{r}0.0001 \\
(0.0000)^{\star \star}\end{array}$ & $\begin{array}{r}0.0001 \\
(0.0000)^{\star \star}\end{array}$ & $\begin{array}{r}0.0001 \\
(0.0000)^{\star \star}\end{array}$ \\
\hline Time after crisis & $\begin{array}{r}0.0348 \\
(0.0282)\end{array}$ & $\begin{array}{r}0.026 \\
(0.025)\end{array}$ & $\begin{array}{l}-0.042 \\
(0.042)\end{array}$ & $\begin{array}{r}0.077 \\
(0.026)\end{array}$ & $\begin{array}{r}0.035 \\
(0.028)\end{array}$ & $\begin{array}{l}-0.018 \\
(0.023)\end{array}$ \\
\hline Time after crisis ${ }^{2}$ & $\begin{array}{r}-0.0053 \\
(0.0015)^{\star \star}\end{array}$ & $\begin{array}{r}-0.0023 \\
(0.0014)\end{array}$ & $\begin{array}{r}-0.0007 \\
(0.0023)\end{array}$ & $\begin{array}{r}-0.0058 \\
(0.0014)^{\star \star}\end{array}$ & $\begin{array}{l}-0.0019 \\
(0.0015)\end{array}$ & $\begin{array}{r}-0.0027 \\
(0.0012)^{\star}\end{array}$ \\
\hline Constant & $\begin{array}{l}-1.076 \\
(0.628)\end{array}$ & $\begin{array}{l}-0.828 \\
(0.559)\end{array}$ & $\begin{array}{l}-1.758 \\
(0.935)\end{array}$ & $\begin{array}{l}-1.099 \\
(0.582)\end{array}$ & $\begin{array}{l}-1.124 \\
(0.633)\end{array}$ & $\begin{array}{r}-0.294 \\
(0.503)\end{array}$ \\
\hline Observations & 278 & 278 & 278 & 278 & 278 & 278 \\
\hline Number of Countries & 29 & 29 & 29 & 29 & 29 & 29 \\
\hline R-squared & 0.36 & 0.46 & 0.30 & 0.36 & 0.51 & 0.40 \\
\hline
\end{tabular}

All regressions include country-specific fixed effects. Standard errors in parentheses.

Significance: ${ }^{*} 5 \%$; ${ }^{* *} 1 \%$ 
Table 9 Cumulative Inflation and Subsequent Inflation

\begin{tabular}{l|rrr}
\hline & \multicolumn{3}{|c}{ Inflation } \\
& $(1)$ & $(2)$ & $(3)$ \\
\hline Lagged EBRD index & 55.355 & 234.517 & 231.533 \\
War & $(484.589)$ & $(422.007)$ & $(619.201)$ \\
& $3,839.13$ & $4,217.13$ & $4,219.20$ \\
Lagged outputfall & $(1,211.194)^{\star \star}$ & $(1,239.001)^{\star \star}$ & $(1,279.563)^{\star \star}$ \\
& 11.216 & & 0.221 \\
Lagged gdp p.c. & $(26.885)$ & & $(33.533)$ \\
(thousands) & & -42.474 & -41.971 \\
Cumulated inflation & & $(131.345)$ & $(152.015)$ \\
& -0.002 & -0.002 & -0.002 \\
Constant & $(0.000)^{\star \star}$ & $(0.000)^{\star \star}$ & $(0.000)^{\star \star}$ \\
& -92.201 & 148.483 & 144.648 \\
\hline Observations & $(1,019.0)$ & $(1,237.3)$ & $(1,368.5)$ \\
Number of Countries & 493 & 482 & 482 \\
R-squared & 27 & 27 & 27 \\
\hline All regressions include & 0.09 & 0.09 & 0.09 \\
\hline
\end{tabular}

All regressions include country-specific fixed effects. Standard errors in parentheses.

Significance: $* 5 \%$; $* * 1 \%$ 
Figure 1 Output Fall

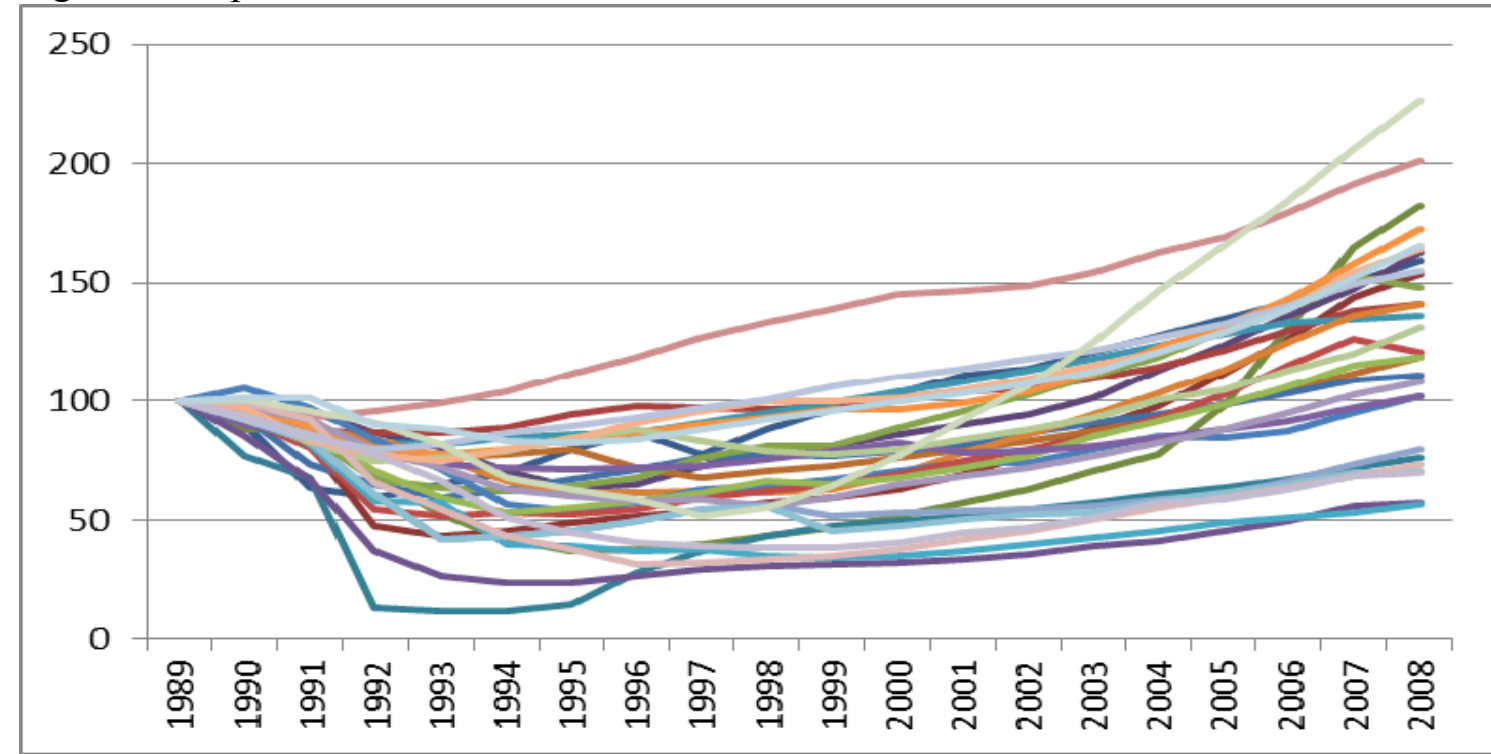

Notes: Output fall measured as index of overall GDP with the 1989 level equal to 100.

Figure 2 Cumulative Inflation

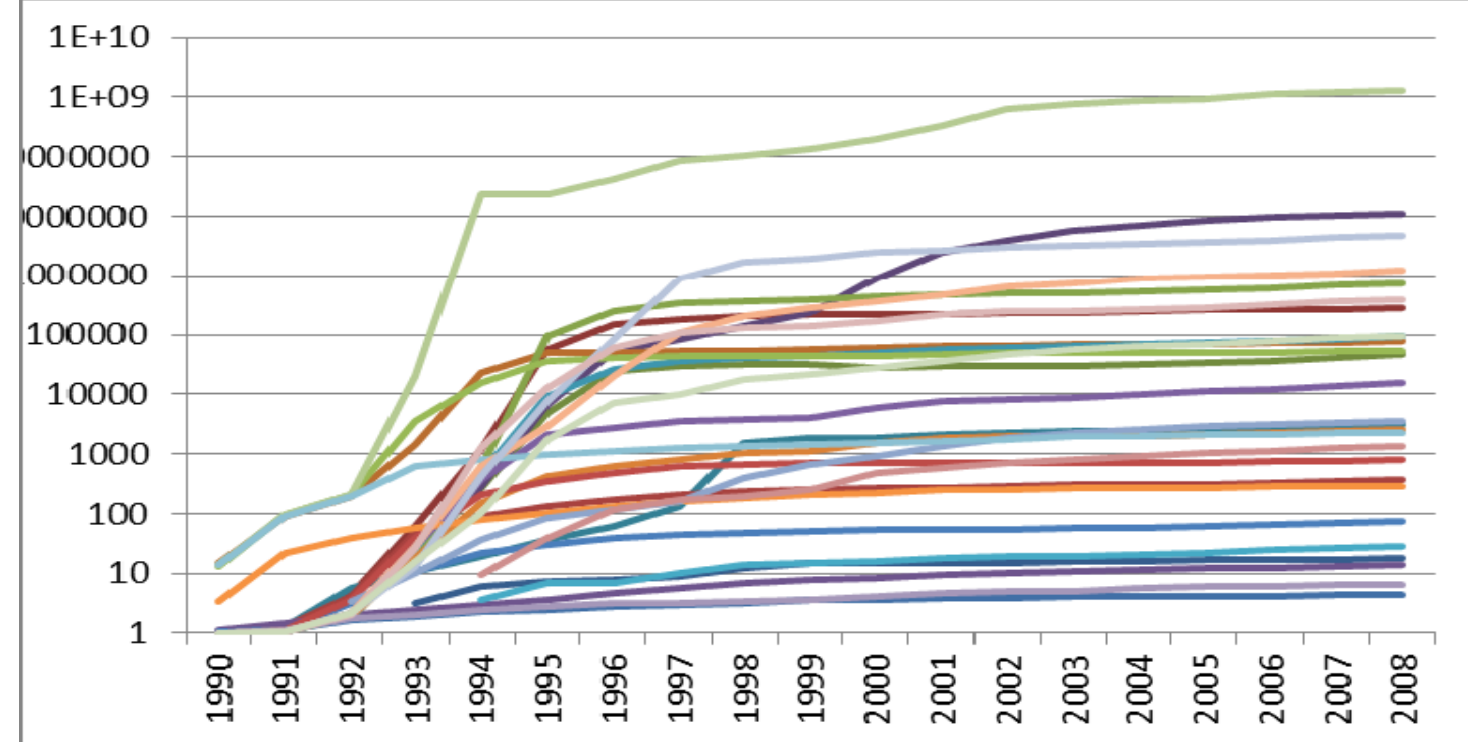

Notes: Cumulative inflation measured as multiple of the starting level (logarithmic scale). 